\title{
A CONGENITAL FORM OF AMAUROTIC FAMILY IDIOCY
}

\author{
BY \\ R. M. NORMAN AND N. WOOD \\ From the Burden Mental Research Department, Stoke Park Colony, and the Pathological \\ Department, Bristol University
}

(RECEIVED 11TH November, 1941)

SINCE the original description of Tay-Sach's disease in the eighties of the last century a group of allied nervous disorders has become recognized, the common pathological feature of which is a ubiquitous distention of the nerve cells with granules of a lipoid nature. Apart from a few anomalous forms it is customary to classify these amaurotic family idiocies according to the time of onset of the disease, infantile, late infantile, juvenile, late juvenile and adult types being described. The resemblance between the infantile type and Niemann-Pick's disease had been noted by Knox, et alia, in 1916, but it was not until Pick and Bielschowsky's $(1927,1928)$ demonstration of the closely similar cerebral pathologies of these two conditions that it became generally realized that disordered lipoid metabolism, not heredodegeneration, was responsible for the granular accumulations in the nerve cells. The consequent inclusion of the amaurotic family idiocies in the category of lipoidoses began a new chapter in the history of these much studied diseases and support for this new theory of pathogenesis has since been received from the occasional finding of the characteristic type of neuronal swelling in the predominantly mesodermal disorders of Gaucher (Lindau, 1930) and of Hunter-Hurler (Ashby, et alia, 1937). Nevertheless, in many, perhaps most, cases of amaurotic family idiocy lipoid storage is confined to the nervous system, and it might well seem a perversion of nomenclature to classify these apparently purely nervous diseases as "lipoidoses" were it not that in some otherwise typical examples of the infantile and juvenile forms unsuspected lipoid storage in the visceral organs has been found on microscopical search (Schob, 1930; Pick, 1932; Brouwer, 1936). The case recorded in this paper belongs to this theoretically important intermediate group which is characterized by the predominantly cerebral localization of the lipoid deposition, the reticulo-endothelial system being involved only in a minor degree. It differs, however, from Tay-Sach's disease in several respects, notably in its congenital character and in the histochemical reactions of the intracellular lipoid. 


\section{Case Report}

Baby C., a full-term female infant, was born after a normal labour in Southmead Hospital, Bristol. The mother's pregnancy had been uneventful. A few days after birth it was noticed that the baby became slightly blue during her feeds and later regurgitated fluids immediately after feeding. A catheter was passed down the œsophagus, but no abnormality was found. Blood was found in the napkins for 5 days before death, which occurred at the age of 18 days and the cause of which was obscure.

Family History.-The father and mother were interviewed. They are normal physically and mentally, are not blood relatives, and have two other normal children. A brother of the father is a certified mental defective. An aunt of the father resided for many years in a Public Assistance Institution suffering from unspecified mental trouble, but is now at her home and is not regarded by her relatives as abnormal. We have been unable to verify this. Apart from these two relatives there is no history of mental illness in the family, and neither parent nor a paternal aunt who was also visited could recall any death in infancy or childhood among the numerous family connections.

Post-Mortem Examination.-The body was rather wasted and severely dehydrated. The skin showed no abnormality. The head appeared small (circumference $28 \mathrm{~cm}$.), but the facies was normal. The lungs were completely aerated and showed a small subpleural hæmorrhage at one point. The larynx appeared small, the trachea being normal and showing no communication with the esophagus. The walls of the ventricles of the heart were equally thick and a patent ductus arteriosus was present which admitted easily a probe $2 \mathrm{~mm}$. in diameter. There was no coarctation of the aorta. At the lower end of the osophagus a small ulcer was found, probably the result of the passage of a catheter during life. There was no congenital abnormality of the gut. A small amount of altered blood was present in the colon, the mucosa of which showed patchy engorgement. Both kidneys showed gross hæmorrhages into a number of individual pyramids. The ureters and urinary bladder were normal, the latter containing blood-stained urine. Spleen, lymph glands, adrenals, thyroid, thymus, pancreas, ovaries and uterus showed no naked eye abnormality. The liver was somewhat pale, but otherwise appeared normal. The calvaria had the usual extent of ossification. A considerable degree of external hydrocephalus was found, a wide fluid filled space being present between the surface of the brain and the dura. Over the superior surface of the hemispheres the leptomeninges floated in loose folds.

Microscopical Examination of the Kidneys.-Massive diffuse hæmorrhages apparently of capillary origin were present between the tubules of the affected pyramids. Many of the tubules contained red blood cells. There was no evidence of organization, leucocytes were scanty and conspicuous amounts of hæmatogenous pigment in the form of fine granules were present. Around the areas of hæmorrhage was a narrow zone of capillary dilatation with some diapedesis of red cells. Large groups of glomeruli, not obviously related to the areas of hæmorrhage, showed engorgement of the glomerular tufts, but otherwise the cortex appeared normal for a child of this age. Changes in the tubular epithelium were probably the result of post-mortem autolysis. Fat staining showed no abnormality.

\section{Macroscopical Examination of the Nervous System}

The meninges stripped easily. The brain was much smaller and lighter than that of a newly born child, its length being $6 \frac{1}{2} \mathrm{~cm}$. and its weight with 
cerebellum and brainstem only $87 \mathrm{gm}$. Cerebellum and brainstem weighed $5 \frac{1}{2} \mathrm{gm}$. The convolutional development was peculiar, the frontal lobes showing a relative pachygyria (Fig. 1). The Rolandic sulci were clearly formed, though neither reached the great longitudinal fissure. The precentral sulcus on the left side was present in two parts, but that of the right side was represented only by a short sulcus in the lateral aspect of the brain. Shallow indentations marked the superior and inferior frontal sulci, the superior frontal gyrus appearing unduly broad for so small a brain while at the frontal pole the cortex was smooth apart from a few irregular undulations. Operculation in the region of the third frontal gyri was well advanced and the insulæ were not unduly exposed. On the ventral aspect of the frontal lobe only the gyri recti were represented. The temporal, parietal and occipital lobes showed a more advanced degree of convolutional development, but no secondary sulci were present. The sulci were shallow and gaped widely in a manner suggestive of atrophy. The cerebellum (Fig. 1) was obviously small compared with the size of the brain as a whole, the lateral lobes in particular being poorly developed, the vermis being entirely exposed and the whole organ appearing dumb-bell shaped. The cerebellar sulci were also shallow and unduly wide and the convolutions adjoining the posterior cerebellar notch appeared completely atrophic. On palpation, the brain was much firmer than normal, but not in a uniform manner, the cortex being softer than the deeper portion of the hemispheres. This deep-seated toughness was more apparent after section of the brain, especially in the thalami and brain stem. There was evidently a gross reduction in the volume of the cortical white matter and the subcortical white matter of the frontal lobe showed a rarefaction and shrinkage of the tissue suggesting a status spongiosus (Fig. 2). The cavum of the septum pellucidum was dilated, but the lateral ventricles showed no obvious hydrocephalus. The corpus callosum was represented by a tough ribbon-like structure widening in the genu and splenium to a width of about $3 \mathrm{~mm}$.

\section{Microscopical Examination of the Nervous System}

Cerebral Cortex.-Numerous representative areas were examined from the left cerebral hemisphere, standard methods for nerve cell bodies, axis cylinders, myelin, lipoid and neuroglia being employed. No abnormality was found in the pia-arachnoid. The cortex was sharply demarcated from the subjacent white matter and measured in depth from $0.8 \mathrm{~mm}$. in the occipital pole to $1.3 \mathrm{~mm}$. in the frontal lobe. When stained by cresyl violet or toluidine blue the grey matter was seen to be richly cellular, an abnormally large astrocytic type of nucleus predominating.

Nerve Cells were by no means obvious owing to the absence of Nissl granules. The most easily recognized were the Betz cells of the precentral gyrus which showed gross swelling and uniform staining of their cytoplasm (Fig. 5). Elsewhere, chiefly in the deeper layers of the pre-frontal, insular and hippocampal areas, nuclei of neuronal type were found in cells showing an 


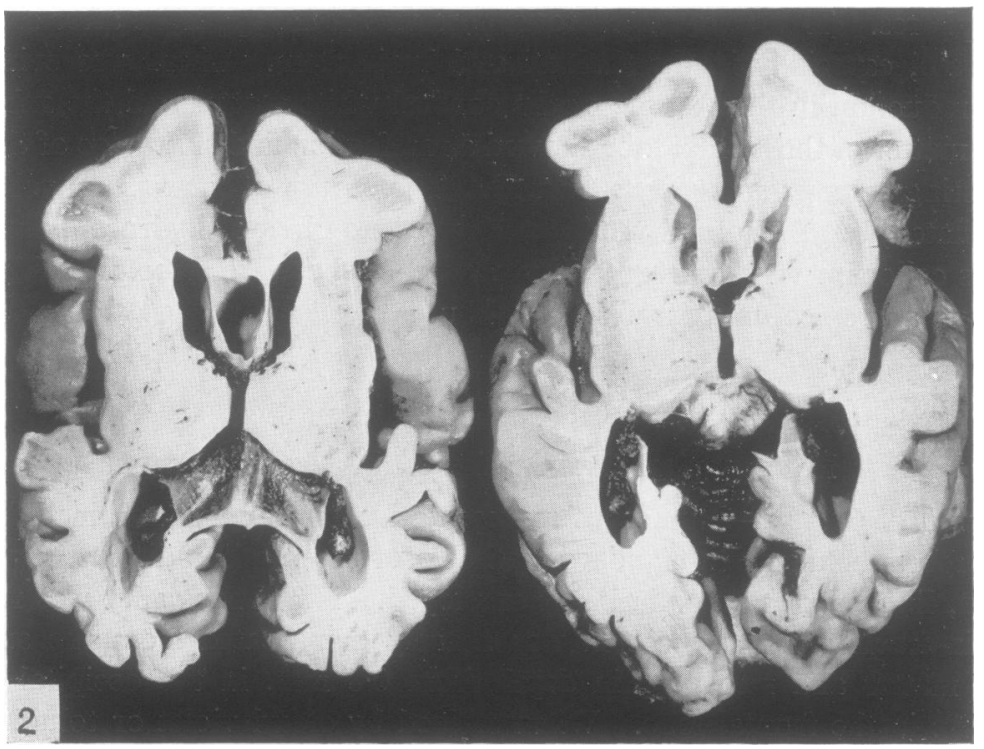

음

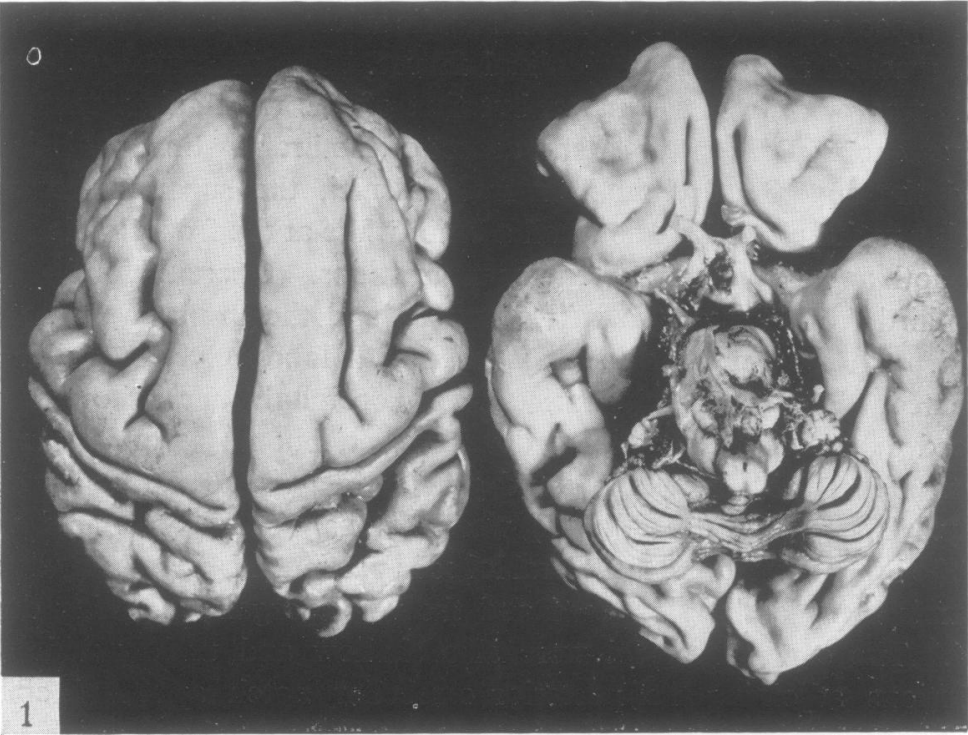


extreme degree of cytoplasmic swelling, feeble staining and ill-defined edges. Bielschowsky staining was not informative, the swollen cell bodies colouring deeply with the silver, but no processes, reticulation, or neurofibrillæ being shown. Staining with Scharlach R. or Sudan III revealed the presence of large amounts of closely packed fine granules of pink or yellowish-red colour in these distended cells. The most conspicuous cell element of the cortex, however, and one that gave an unusual appearance to all areas examined, will now be described. Scattered in varying concentration throughout the outer part of the grey matter and forming a dense band in the deeper third of the cortex were large cells 13 to $20 \mu$ in diameter, usually round in shape but occasionally of irregular contour. Numerically they greatly exceeded the obvious nerve cells described above. Cresyl violet stained their cytoplasm with a variable degree of intensity, usually in a uniform manner, but occasionally with a suggestion of granularity in the peripheral portion (Fig. 3). Lipoid stains showed them to be completely filled with fine granules colouring in the same manner as those of the nerve cells (Fig. 4). No processes or neurofibrillæ were demonstrable. Their nuclei, which differed from those of neurones or astrocytes, varied considerably in size and shape, stained darkly, were generally somewhat eccentric in position and often situated at the edge of the cell. A large, round nucleus about $7 \mu$ in diameter was the most frequent type, though polygonal, small round and irregularly oval forms were common. In the main these irregularly shaped nuclei appeared shrunken and pyknotic with crenated edges and small peripheral nodules and excrescences, and they occasionally took the form of tortuous deeply staining rods or threads. Two nuclei were sometimes present in one cell. Rarely, a single centrally placed chromatin granule suggested a pathologically altered nerve cell nucleolus. These peculiar cells were absent from the molecular layer and white matter and were exclusively found in areas normally occupied by nerve cells. Their size did not vary with their position in the cortex either as regards lamina or cortical area: they were as large in the granular postcentral and calcarine areas as in the agranular parts of the frontal cortex. In the hippocampus they formed not only the majority of cells in the area pyramidalis subiculi (H.E $\mathrm{E}_{2}$ of von Economo), but also of the granular layer of the dentate gyrus the cells of which, while retaining their cap-like formation, had lost their normal granular appearance and consisted of a thin layer of large lipoid-laden cells. In the molecular layer of the frontal cortex Cajal cells were frequently found. These also showed swelling of the amaurotic idiocy type, but to a less degree than did the nerve cells elsewhere. In addition to the cell types described the cortex also contained numerous small, darkly staining nuclei similar to those commonly seen in immature brains. These were chiefly concentrated in the superficial part of the grey matter and were especially conspicuous in the calcarine cortex.

Staining Reactions and Solubility of the Granular Substance.-The granules in the nerve cells and in the peculiar round cells described above had identical histochemical properties. They stained a deep pink or yellowish-red with Scharlach R., less deeply with Sudan III, dark blue with Nile blue sulphate and greyish-black with Weigert's iron hæmatoxylin. Osmic acid did not affect 

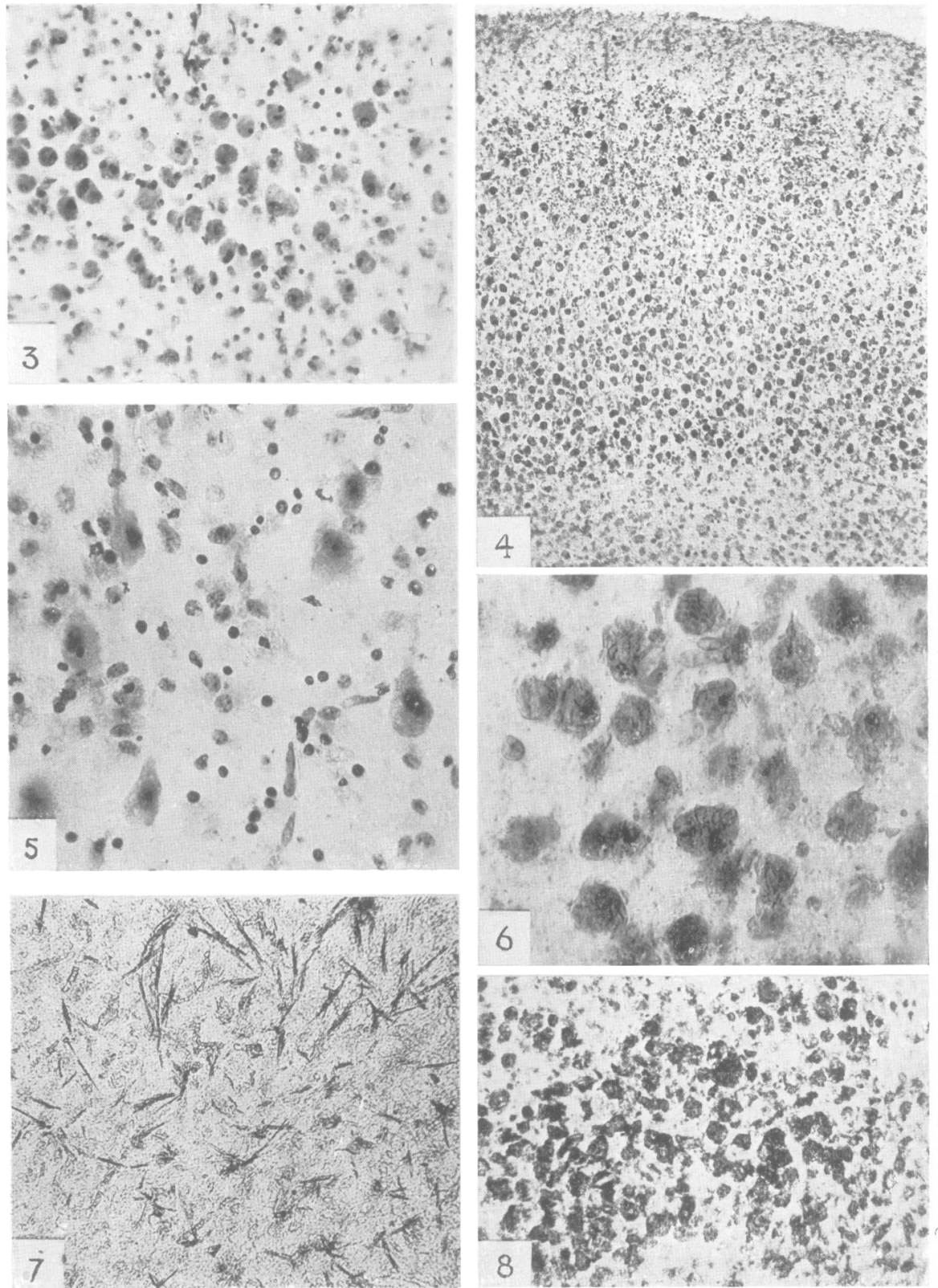

Fig. 3.-Deeper layers of occipital cortex showing rounded, lipoid-laden cells. Cresyl violet. $\times 180$.

Fig. 4.-Occipital cortex. Scharlach R. and Anderson's acid hæmatoxylin after treatment of section with chloroform. $\times 60$.

Fig. 5.-Betz cells showing swelling and loss of Nissl substance. Toluidine blue. $\quad \times 270$.

Fig. 6.-Astrocytes of subcortical white matter showing crystalline deposits and lipoid granules. Scharlach R. and hæmatoxylin. $\times 360$.

Fig. 7.-Extracellular acicular crystals of cholesterol esters in subcortical white matter. Osmic acid. $\times 100$.

Fig. 8.-Focus of heavy lipoid deposition in corpus callosum. Scharlach R. and hæmatoxylin. $\times 100$. 
them. Using Anderson's modification of the Kultschitsky-Pal method a black coloration appeared in the cells after 5 days mordanting, though even then differentiation was rapid and the results variable. The granules were not doubly refractile. They were insoluble after prolonged soaking of sections in acetone, methyl alcohol, ethyl alcohol, ether, xylol, pyridine, chloroform or equal parts of ether and methyl or acid alcohol. Boiling chloroform had little effect on subsequent staining save that the granules became more discrete (Fig. 4) and lost a little of their red colour.

Neuroglia.-Astrocytes were proliferated in all layers of the cortex... In the molecular layer elongated bipolar forms were arranged in a roughly vertical manner. In the outer part of the grey matter large fibrillary astrocytes (Fig. 9) sometimes of astroblastic shape (Fig. 10) were attached to thickened arterioles by their sucker feet. In the deeper layers fat-bodied astrocytes with numerous short, wavy processes were the predominant type (Fig. 11). In most of these cells, especially the last, there were present small deposits of yellowish granules resembling those in the nerve cells but less closely packed.

Subcortical White Matter.-Axis cylinders appeared to be absent from all regions of the hemispheres. A great increase in the number of astrocytes was present, the majority appearing as gemästete cells with large oval cytoplasm staining palely with cresyl violet. The nucleus of normal astrocytic type occupied a polar position. While many large fiber-forming cells were present the gliosis was in the main astrocytic not fibrillary in type (Fig. 13). Scharlach R. staining revealed massive lipoid deposition, the whole white matter appearing pink to the naked eye. The cell bodies of the astrocytes were loaded with lipoid granules staining a bright pink. This substance stained greyish-black with the Kultschitsky-Pal method after two days mordanting. It was not doubly refractile and was not blackened by osmic acid. In unstained sections large numbers of extracellular birefringent acicular crystals were seen in the white matter (Fig. 7). In many areas these crystals encrusted the bodies of the astrocytes, sometimes appearing embedded in the non-refractile lipoid contents of the cytoplasm (Fig. 6). Particularly heavy deposits of doubly refractile crystals and droplets formed foci in the deeper parts of the white matter, especially near the ventricle and in the corpus callosum (Fig. 8). In these situations the cell outlines were obscured by the quantity of the deposit. Impregnation methods, however, demonstrated the presence in these foci of phagocytic cells varying in size from that of ordinary compound granular corpuscles to foam cells $30 \mu$ in diameter. This anisotropic material had the properties of cholesterol esters. It was readily soluble in acetone. It was darkened by osmic acid and stained deeply with Scharlach and Sudan III. When heated to $50^{\circ} \mathrm{C}$. its powers of double refraction were lost, being restored on cooling the section. Chloroform extracts of pieces of the white matter gave a strong Salkowsky reaction for cholesterol, fully equal to that obtained from adult myelinated white matter and far more intense than in control material taken from a normal 14 days' brain. Extracellular droplets of neutral fat were also numerous in the white matter. After treating sections with solvents the bulk of the red staining lipoid disappeared, leaving conspicuous deposits of 


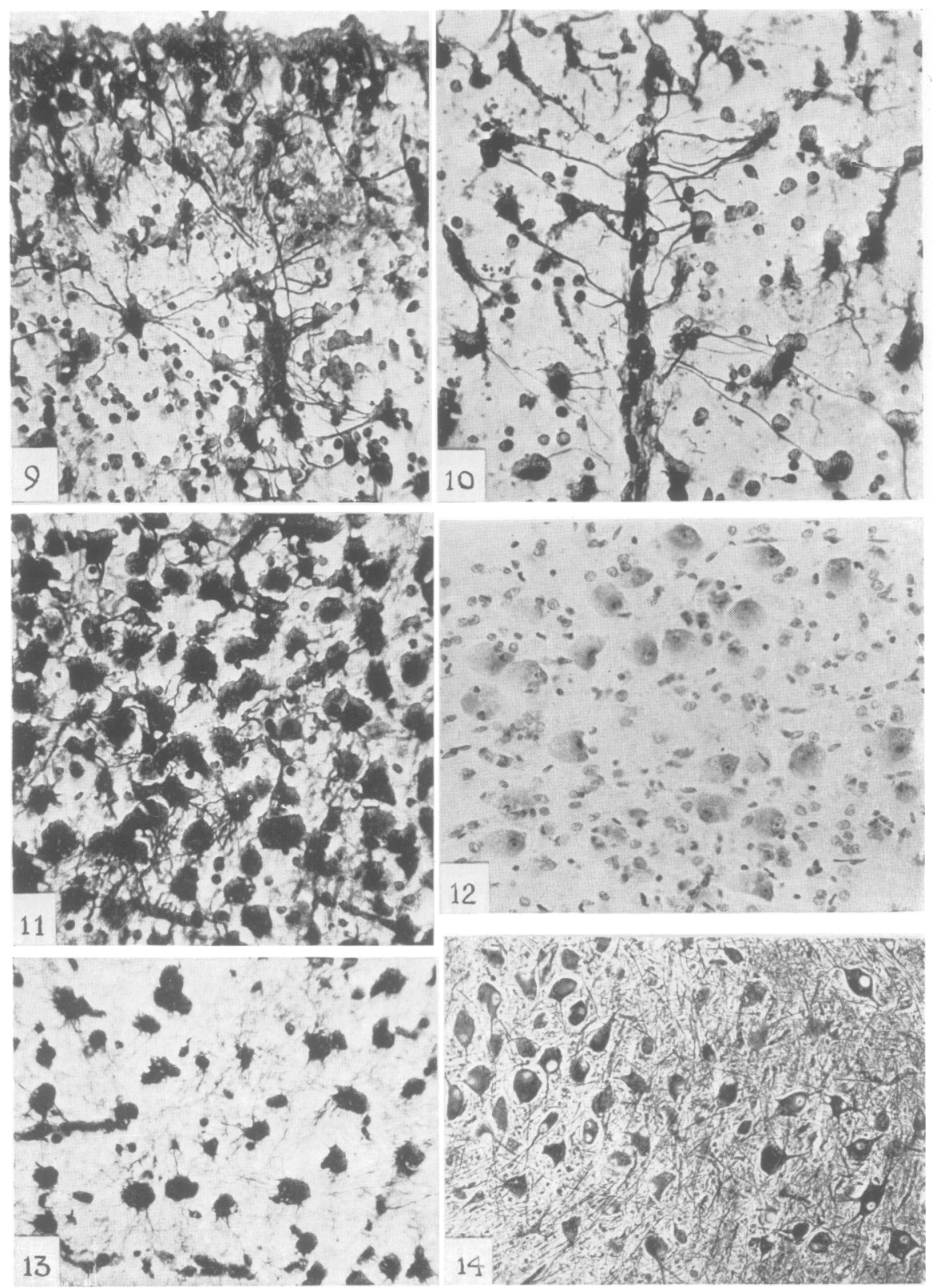

Fig. 9.-Gliosis in superficial layers of cortex. Hortega's method for astrocytes. $\times 270$.

Fig. 10.-Astroblastic cell types in insular cortex. Hortega's method for astrocytes. $\times 360$.

Fig. 11.-Lipoid-laden astrocytes in deeper layers of cortex. Hortega's method for astrocytes. $\times 270$.

Fig. 12.-Nerve cells of thalamus showing swelling of amaurotic family idiocy type. Cresyl violet. $\times 180$.

Fig. 13.-Astrocytes of subcortical white matter with fine fibrils. Hortega's method for astrocytes. $\times 270$.

Fig. 14. -Nerve cells of trochlear nucleus showing swelling. Bielschowsky's method. $\times 80$. 
insoluble yellowish-red granules in the cell bodies of the astrocytes. Dense aggregations of nuclei (" germinal centres ") were present in the subependymal region of the white matter.

Optic Nerve, Chiasma, and Tract.-There was almost complete absence of myelinated fibres, three or four being present in longitudinal sections of the optic nerve, a somewhat higher proportion in the tract.

Blood Vessels.-Arterioles showed thickening of the advential layer with proliferation of mesenchymal fibrils. A few yellowish granules were sometimes seen in the vessel walls, but no neutral fat deposits were present.

Cerebellum.-Sections made through the vermis and left lateral lobe showed widespread and intense atrophy of nerve cells, the granular layer being recognizable only in a few folia of the anterior part of the hemisphere, the inferior vermis and the flocculus. The molecular layer was extremely narrow and in most areas a well-marked superficial layer of granules was present. Lipoid staining revealed the presence of large, round cells filled with granules scattered throughout the grey matter of the cerebellar cortex (Fig. 15). In the less atropic folia of the flocculus these cells were regularly arranged at the junction of molecular and granular layers. Impregnation methods failed to demonstrate processes save in one or two rare instances where a faint outline of Purkinje dendrites was seen. In its histochemical properties the granular material resembled that found in the nerve cells of the cerebral cortex. The cerebellar cortex was devoid of nerve fibres while the white matter contained only an occasional axis cylinder. Myelin was entirely absent from the cerebellum and its peduncles. No neutral fat was seen in the walls of the blood vessels. There was extensive proliferation of macroglia in all layers (Fig. 16). Swollen glial cells loaded with lipoid were present in the white matter. Extracellular doubly refractile crystals were found with great regularity in the molecular layer and central white matter.

Dentate Nucleus.-The nerve cells showed no numerical loss, but were represented by grossly swollen, round forms filled with insoluble granules, resembling closely the lipoid-laden cells found elsewhere in the cerebral and cerebellar cortices. Holzer staining showed a dense fibrillary gliosis marking the outline of the dentate nucleus.

Basal Ganglia.-Sections made at different levels through the left half of the brain showed a dense cellularity in putamen and caudate nuclei, numerous round cells loaded with lipoid being present. Apart from some of the larger nerve cells it was difficult to distinguish neurones from astrocytes, the staining reactions and insolubility of the granules being the same in both. Selective staining, however, revealed an overgrowth of large astrocytes with little formation of fibres. In the globus pallidus the nerve cells showed great swelling with retention of the normal type of nucleus. Changes typical of amaurotic family idiocy were also found in both thalami where greatly enlarged oval forms with well stained neuronal nuclei displaced to one pole gave a characteristic picture (Fig. 12). Bielschowsky staining showed that most of these cells retained their processes and that the cytoplasm was finely reticulated. There were also numerous rounded forms with few or no processes and a uniform 

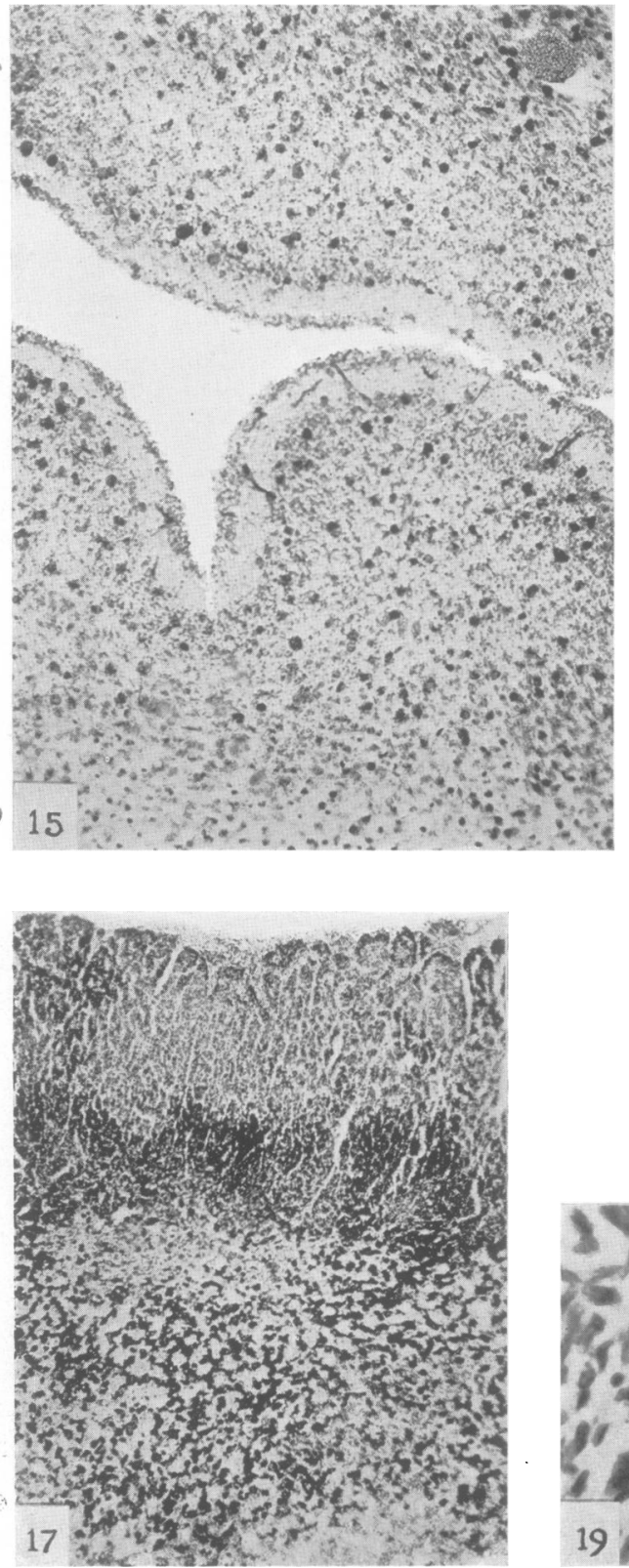
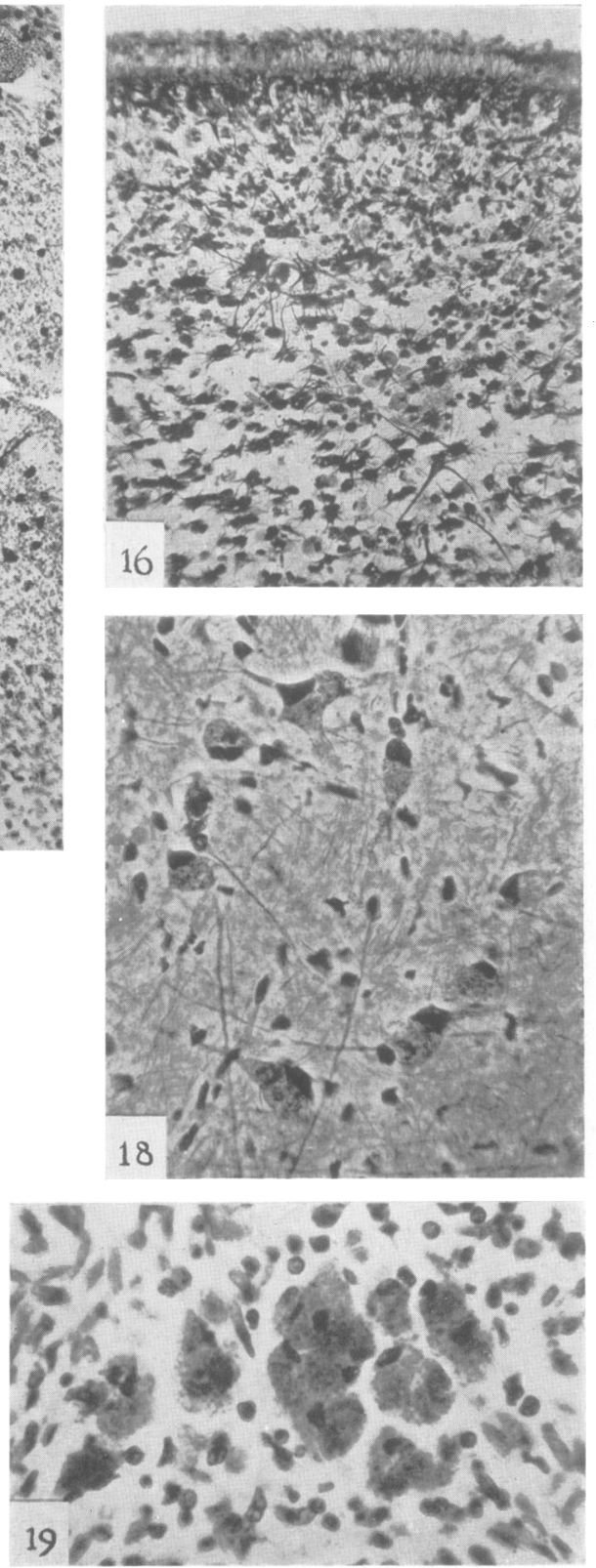

Fig. 15.-Cerebellum. Folia from lateral lobe showing atrophy of internal granular cells, a superficial granular layer and large lipoid-laden cells. Scharlach $R$. and hæmatoxylin. $\times 60$.

Fig. 16.-Cerebellum. Gliosis in all layers. Extremely narrow molecular layer with proliferated Bergmann glia. Hortega's method for astrocytes. $\times 180$.

Fig. 17.-Suprarenal. Lipoid-laden cells in medulla. Scharlach R. and hæmatoxylin. $\quad \times 40$.

Fig. 18.-Pons. Small nerve cells showing swelling of amaurotic type. Bielschowsky's method. $\times 270$.

Fig. 19.-Spleen. Lipoid-laden phagccytes. Hortega's 1927 method for macrophages. $\times 450$. 
dust-like staining of the cell body. Unmyelinated axis cylinders were plentiful. Glial nuclei were increased in number and a heavy fibrillary gliosis was present. The cell bodies of the astrocytes in this situation contained less lipoid than elsewhere in the basal ganglia so that the nerve cells appeared more prominent.

The internal capsule contained no demonstrable nerve fibres and the anterior limb was barely recognizable. The broader posterior limb contained conspicuous deposits of doubly refractile lipoid staining deeply with Scharlach and osmic acid, and a greyish colour with the Kultschitsky-Pal method. Around these deposits, which also occurred in the external capsule, there had developed a coarse network of glial fibres.

Brain Stem.-All the nerve cells showed swelling of the amaurotic idiocy type (Figs. 14 and 18), the large cells of the cranial nerve nuclei in the neighbourhood of the aqueduct being particularly affected. The granular substance found in the neurones stained yellowish-pink with Scharlach and was insoluble in lipoid solvents. Relatively small amounts of intracellular lipoid was sometimes seen in these greatly expanded cells. Swelling in the dendrites was occasionally present in the smaller nerve cells. The nerve cells of the mesencephalic root of the fifth nerve appeared normal. Gross atrophy of the inferior olives was present, only a few round lipoid-laden cells remaining. The olives did not exhibit their normal crenated appearance and were the seat of heavy gliosis. The medullary pyramids were absent. A marked proliferation of fibrous astrocytes was found throughout the brain stem and in the basilar part of the pons a dense fibrillary gliosis was seen in Holzer preparations. As elsewhere, the bodies of the astrocytes contained lipoid granules, but not to the same degree as in the white matter of the hemisphere. Myelin was recognized for the first time in the midbrain and lower levels, but was present in considerably less amount than in control sections made from the brain of a newly born child. The nerve roots of the third, fourth, fifth, seventh and twelfth cranial nerves and a narrow band of fibres emerging from the hila of the olives, were sufficiently well stained to be visible to the naked eye. Microscopic examination showed a feeble myelinization in a minority of fibres in the medial lemniscus, medial longitudinal fasciculus, the dorsal decussation. the decussating fibres of the pontine raphe and in the restiform body. The superior and middle cerebellar peduncles were unmyelinated.

Spinal Cord.-In sections from the short portion of the cervical cord which was available no axis cylinders were seen in the portion normally occupied by the lateral and ventral pyramidal tracts. The dorsal and ventral roots were myelinated. The posterior columns of the cord contained a full complement of nerve fibres, but myelin sheaths were almost absent. Of the remaining tracts, the spino-cerebellar and the fasciculi proprii of the anterior funiculus were sufficiently myelinated to show up without magnification. Elsewhere scattered myelin sheaths were found only on microscopical examination. The nerve cells of the grey matter were all affected by the lipoid change.

Lipoid Abnormalities in the Visceral Organs.-Portions of the spleen, liver, and suprarenals and a few of the mesenteric and para-aortic lymph nodes had fortunately been preserved and were available for examination. In the spleen, 
groups of phagocyte cells were found filled with granules having the same staining reactions and insolubility as the nerve cells. These cells averaged $20 \mu$ in diameter and had the appearance of reticulo-endothelial macrophages. They did not present the wrinkled surface of Gaucher cells nor the vacuolation of " foam" cells. Groups were occasionally found in the neighbourhood of arterioles in the Malpighian bodies (Fig. 19), but although a conspicuous feature of all sections stained with Scharlach they were not sufficiently numerous to disturb the normal architecture of the organ. The hæmosiderin content of the spleen was not excessive. Similar cells were found in relatively larger numbers in the lymph nodes. The liver was less affected, only the Kupfer cells being involved.

In the suprarenal medulla large numbers of lipoid-laden cells were present (Fig. 17). This lipoid was doubly-refractile and stained a deep red with Scharlach. After treatment with alcohol an insoluble residue of yellowish isotropic granules remained. The lipoid of the suprarenal cortex was not doubly-refractile and after treatment with solvents small quantities of yellowish granules remained in most of the cells.

\section{Discussion}

Although from the point of view of nerve cell morphology this case evidently belongs to the amaurotic idiocy group several features distinguish it from the infantile form. The main points of difference are summarized in the table below, the statements made regarding the lipoid abnormalities of Tay-Sach's disease being taken from Hurst's (1925) well-known study.

Elaborating some of these contrasting features one may first draw attention to the insolubility of the granular material present in the nerve cells and glia of our case which more resembles the lipochrome-like substance found in the juvenile form than the prelipoids of Tay-Sach's disease. This extreme insolubility is a property of the nerve cell deposits in Hunter-Hurler's disease (Ashby, et alia, 1937), and has been noted in association with tuberose sclerosis in the brain of a year old infant (Norman, 1940). In both these conditions, however, the nerve cell swelling was of the moderate degree found in juvenile amaurotic idiocy, and the astrocytes were not implicated in the process of lipoid storage. There was, moreover, nothing clinically to suggest gargoylism in the present case.

Another peculiar finding was the widespread deposition in the white matter of doubly refractile crystals having the microchemical reactions of cholesterol esters. Chemical tests indicated that the cholesterol content of this unmyelinated "white matter" very significantly exceeded that of a normal brain of similar age and was quite up to the level of normal adult myelinated tissue. Since in the present case these extracellular cholesterol compounds cannot have been derived from myelin breakdown, it must be assumed that they have been deposited from the blood stream, though what factors may have conditioned this phenomenon are obscure. One is confronted with a some- 
what similar problem in the Hand-Schüller-Christian syndrome in which, although hypercholesterinæmia may be an important prerequisite, various other local factors of an undetermined character are essential for the massive localized depositions that may occur in the brain (Chiari, 1933). Small amounts of cholesterol compounds may be present in the gitter cells of infantile amaurotic idiocy (Hurst, 1925) and also mixed with the phosphatide in the cell inclusions of Niemann-Pick's disease, but excessive extracellular deposition of the sort found in this case appears to be a unique finding.

TABLE 1

\begin{tabular}{|c|c|c|c|}
\hline & & $\begin{array}{l}\text { INFANTILE AMAUROTIC } \\
\text { FAMILY IDIOCY }\end{array}$ & CONGENITAL TYPE \\
\hline Age at onset .. & . & $\begin{array}{l}\text { At least } 3 \text { months: may be con- } \\
\text { siderably later. }\end{array}$ & Foetal life. \\
\hline Size of brain . . & . & $\begin{array}{l}\text { Well up to average: often un- } \\
\text { duly massive. }\end{array}$ & Extreme micrencephaly. \\
\hline Nerve cells $\ldots$ & $\cdots$ & $\begin{array}{l}\text { Marked swelling. Nucleus not } \\
\text { often grossly altered. Den- } \\
\text { dritic swelling frequent and } \\
\text { pronounced. }\end{array}$ & $\begin{array}{l}\text { Large numbers of spherical cells } \\
\text { with atypical nuclei in cerebral } \\
\text { cortex. Dendritic swelling un- } \\
\text { common. }\end{array}$ \\
\hline Nerve cell lipoid & . & $\begin{array}{l}\text { Phosphatides and cerebrosides. } \\
\text { Mostly readily soluble in } \\
\text { alcohol and chloroform, but } \\
\text { small cells may contain a resi- } \\
\text { due insoluble in acid alcohol- } \\
\text { ether mixture but soluble in } \\
\text { xylol. }\end{array}$ & $\begin{array}{l}\text { Insoluble. Resists xylol or boil- } \\
\text { ing chloroform. }\end{array}$ \\
\hline Neuroglia & . & Heavy fibrillary gliosis usual. & Gliosis mainly astrocytic. \\
\hline Neuroglial lipoid & . & Soluble as in nerve cells. & $\begin{array}{l}\text { There is a soluble fraction, but } \\
\text { the bulk is insoluble as in nerve } \\
\text { cells. Total deposition more } \\
\text { massive than in Tay-Sach's } \\
\text { disease. }\end{array}$ \\
\hline Neutral fat $\ldots$ & $\cdots$ & $\begin{array}{l}\text { Common in gitter cells and } \\
\text { blood vessels walls. }\end{array}$ & $\begin{array}{l}\text { Absent from grey matter. Extra- } \\
\text { cellular droplets in white matter } \\
\text { of hemisphere. }\end{array}$ \\
\hline Cholesterol esters & . & $\begin{array}{l}\text { Small amounts sometimes seen } \\
\text { in gitter cells (chiefly peri- } \\
\text { vascular). }\end{array}$ & $\begin{array}{l}\text { Heavy extracellular crystalline } \\
\text { deposits throughout white } \\
\text { matter of cerebrum and cere- } \\
\text { bellum. Often seen in cell } \\
\text { bodies of astrocytes and phago- } \\
\text { cytes in white matter. }\end{array}$ \\
\hline
\end{tabular}

One of the more difficult points of histological interpretation met with in this case concerned the identity of the numerous rounded lipoid-laden cells of the cerebral cortex. While some of these closely resembled the phagocytic form of microglia, the large size and bizarre variations in shape of the nuclei in the majority were not at all characteristic of compound granular corpuscles. Moreover, the absence of any concentration of these cells around blood vessels 
or in the meninges gave no support to the view that they were endothelial macrophages. In Niemann-Pick's disease, Hassin (1930) has drawn attention to the difficulty in distinguishing between some of the spherical inflated nerve cells with pyknotic nuclei and gitter cells, the neutral fat droplets of the latter often being the sole reliable criterion. The cortical cells of our case, however, contained no neutral fat and despite their atypical nuclei it is difficult to avoid the conclusion that these apparent phagocytes are, in fact, a variety of nerve cell the modified structure of which has been conditioned by the fœtal onset of the lipoidosis. That these cells are neurones is strongly suggested by their exclusive localization in the grey matter, their uniform distribution in the ontogenetically older layers of the cortex, their great numerical preponderance over less altered nerve cells, and the similar histochemical reactions of their granular contents to that of undisputed nerve cells in other parts of the brain. Nor is the occasional presence of two nuclei hard to reconcile with this view since multinuclear nerve cells are not uncommon in many different pathological conditions arising in early life. The lipoid abnormalities of Niemann-Pick's or Tay-Sach's disease affect nerve cells which have attained some degree of post-natal maturity, and it is not surprising to find less differentiated and more distorted cell forms in the earlier variety of lipoidosis described here. The same line of reasoning may be applied to the large round cells of the cerebellar cortex which also are reminiscent of those found in Niemann-Pick's disease (Schaffer, 1930), though the insolubility of their granular contents and the absence of lipoid in the walls of the blood vessels are points of difference between the two conditions. The regular arrangement of many of these cells at the junction of molecular and granular layers leaves little doubt that they were Purkinje neurones. Those of similar appearance scattered throughout the atrophic granular layer may be regarded with some justification as heterotopic examples of the same cell type since the general configuration of the cerebellum, its stunted gyri, and the retention of the fœtal superficial layer of granules indicate a retardation in development in addition to the obvious atrophy of the organ.

The fœtal onset of the lipoidosis may also have played an important part in the production of the extreme micrencephaly. Since the rapid increase in weight of the normal brain during early life is largely due to myelinization it would seem likely that the extensive arrest of this process found in the present case was responsible at least in part for the small size and weight of the brain. It is not easy to reconcile this theory, however, with the pathological findings in Tay-Sach's disease in which the brain, though often grossly defective in myelin may yet attain abnormally large dimensions. In one of Bielschowsky's cases the brain weighed 1,690 gm. and that recorded by Steegmann and Karnosh (1936) reached the figure of 2,300 gm. Possibly the great proliferation of neuroglial fibres found in such large brains (as in the case of Holmes, 1911) may account for this excessive weight. In Steegmann and Karnosh's case it was observed that the head increased considerably in size during the last eight months of life. In our congenital form time was presumably lacking for the production of a fibrillary gliosis of such magnitude. 
In Tay-Sach's disease much of the myelin deficiency is due to demyelinization of incompletely developed sheaths (Bertrand and van Bogaert, 1934), though a coincident arrest of myelinization is no doubt an associated factor. In our case it would appear that the latter process was the more important. The almost complete absence of myelin in the posterior columns of the cord which contained, nevertheless, a full complement of axis cylinders is particularly remarkable, since this fibre system is normally conspicuously myelinated at birth. Such abnormalities, whether resulting from lack of formation of myelin or malnutrition of pre-existing sheaths have been attributed by Bielschowsky to a disturbance of the normal lipoid metabolism of the glia. In this respect Tay-Sach's disease has much in common with the juvenile form of diffuse sclerosis described by Scholz (1925) and by Bielschowsky and Henneberg (1928). In this connection it may be pointed out that the widespread glial proliferation present in our case cannot be regarded as secondary to myelin degeneration, and would appear to be as much a primary feature of the disease as is the nerve cell swelling.

A further similarity with the infantile form of amaurotic idiocy is seen in the severe atrophy of the cerebellum, especially in its granular layer. Though commoner in the late infantile form this special involvement of the cerebellum has been often noted in Tay-Sach's disease (Westphal, 1917; Dollinger, 1919; Bielschowsky, 1921; Globus, 1923; Ostertag, 1925; Steegmann and Karnosh, 1936). The advanced olivary atrophy found in our case is, however, distinctly unusual.

In this discussion we have stressed the fœtal onset of the pathological process as accounting for many of the peculiar features of this brain. To what extent the lipoid abnormalities of Tay-Sach's disease antedate the onset of the clinical symptoms it is impossible to say. The fact remains, however, that in the great majority of cases no untoward signs are observed until at least three months of postnatal life have elapsed. In the unique case described by Ostertag (1925) pachygyria and microgyria of the cerebral cortex were present, but as the pathological findings were in other respects typical of the infantile form it would seem likely that the malformation was coincidental. In our case the delayed convolutional development of the frontal lobes was not associated with the microscopical picture of pachygyria.

In conclusion it may be said that although in many respects this congenital case has affinities to the infantile form, there are more points of contrast than of similarity. In particular, the insolubility of the intracellular granular inclusions weigh heavily against the view that one is dealing here merely with a forme fruste of Tay-Sach's disease. While the family history of this isolated case gives no suggestion of a genetic origin for the condition, we feel justified in applying to it the name " congenital amaurotic family idiocy," thus drawing attention to its relationship to the other members of this group of lipoid dyscrasias. 


\section{Summary}

An unusual form of lipoidosis is described in an 18-day old female infant, dying from bilateral hæmorrhages into the renal pyramids. At postmortem the brain was found to be considerably reduced in size and weight $(87 \mathrm{gm}$.) and there was retarded convolutional development in the frontal lobes. Microscopically the nerve cells showed swelling of the amaurotic family idiocy type, the intracellular lipoid being resistive to solvents. Numerous atypical nerve cells showing extreme distention with this material were present throughout the cerebral and cerebellar cortices. Lipoid abnormalities were conspicuous in the glial cells, myelinization was retarded throughout the nervous system, and heavy deposits of extracellular doubly-refractile crystals of cholesterol esters were present in the white matter of the hemispheres and cerebellum. There was a severe olivocerebellar atrophy.

Microscopical examination of the viscera showed evidence of lipoid storage in the reticuloendothelial system, the histochemical reactions of the deposited substance resembling those of the nerve cell granules.

Several points of difference between this condition and Tay-Sach's disease are discussed, and it is concluded that the case is a hitherto undescribed variety of lipoidosis for which the name "congenital amaurotic family idiocy" is suggested.

It is a pleasure to acknowledge Professor T. F. Hewer's kindness in permitting us to examine the brain in this case. We are greatly indebted to Dr. J. G. Greenfield for his very helpful interest in the neuropathological findings.

\section{REFERENCES}

Ashby, W. R., Stewart, R. M., and Watkin, J. H. (1937). Brain, 60, 149.

Bertrand, I., and van Bogaert, L. (1934). Enchéphale, 29, 505.

Bielschowsky, M. (1921).J. Psychol. Neurol., 26, 123.

- (1928). Ibid., 36, 103.

Bielschowsky, M., and Henneberg, R. (1928). Ibid., 36, 131.

Brouwer, B. (1936). Proc. roy. Soc. Med. Lond., 29, 579.

Chiari, H. (1933). Virchows Arch., 288, 527.

Dollinger, A. (1919). Z. Kinderheilk., 22, 167.

Globus, J. (1923). Z. ges. Neurol. Psychiat., 85, 424.

Hassin, G. B. (1930). Arch. Neurol. Psychiat. (Chicago), 24, 61.

Holmes, G. (1911). Proc. roy. Soc. Med. Lond., 4, 199.

Hurst, E. W. (1925). Brain, 48, 1.

Knox, J., Wahl, R., and Schmneisser, H. C. (1916). Johns Hopk. Hosp. Bull., $27,1$.

Lindau, A. (1930). Acta Psychiat., 5, 167.

Norman, R. M. (1940). Arch. Dis. Childh., 15, 244.

Ostertag, B. (1925). Arch. Psychiat., Nervenkr., 75, 355.

Pick, L. (1932). Amer. J. med. Sci., 185, 453.

Pick, L., and Bielschowsky, M. (1927). Berl. klin. Wschr., 34, 1,631.

Schaffer, K. (1930). Arch. Psychiat., Nervenkr., 89, 814.

Schob, F. (1930). " Pathologische A natomie der Idiotie." Bumke's Handbuch der Geisteskrankheiten, vii, Berlin, p. 779.

Scholz, W. (1925). Z. ges. Neurol. Psychiat., 99, 651.

Steegmann, A. T., and Karnosh, L. J. (1936). Amer. J. Psychiat., 92, 1,413.

Westphal, A. (1917). Arch. Psychiat., Nervenkr., 58, 248. 